Citation: Levyk, B., Aleksandrova, O., Khrypko, S., \& latsenko, G. (2020). Geo-policy and Geopsychology as Cultural Determinants of Ukrainian Religion, Mentality, and National Security. Journal of History Culture and Art Research, 9(3), 217-225. doi:http://dx.doi.org/10.7596/taksad.v9i3.2761

\title{
Geo-policy and Geo-psychology as Cultural Determinants of Ukrainian Religion, Mentality, and National Security
}

\author{
Bogdan Levyk ${ }^{1}$, Olena Aleksandrova ${ }^{2}$ \\ Svitlana Khrypko ${ }^{3}$, Ganna latsenko ${ }^{4}$,
}

\begin{abstract}
The interconnection between national religious, mental features and geopolitical, geo-psychological factors regarding national security is considered in the paper. The direct and indirect impact of geopolicy and geo-psychology on religious culture, world view, and mentality of the Ukrainian nation is determined. The existence of stable marginal tendencies, that are inherent in Ukrainian culture and mentality, is highlighted. The main concept of the study was formed in the following statement - the geopolitical circumstances (enhanced by the constant presence of internal territorial "borderline") were not in favor of national unity in the Ukrainian history. The situation caused "instability" and "split" of Ukrainian being as well as national mentality displays. The marginal tendencies of Ukrainian mentality are derived from the geopolitical factor of national being. The dual nature of legal and cultural aspects is presented in the process of the national security establishment. Mental, cultural, and historical memory able to imprint every moment that is beyond legal documents' capacity, is distinguished within the context. The abovementioned memory becomes a basis for the national security idea's realization. The initial aim of the paper is to follow geopolitical and geo-psychological features of national, mentality, religious culture and ideas of national security through structural analysis and hermeneutic methodology; to represent the unique "borderline" of Ukrainian geopolitical, cultural, and mental being; to highlight the character and sources of marginal tendencies in Ukrainian spiritual culture. The additional goal is to demonstrate that the legal establishment of national security principles should be based on the cultural and mental factors.
\end{abstract}

Keywords: Mentality, National consciousness, Culture, National security, Geo-policy, Geo-psychology.

\footnotetext{
1 Doctor of Historical Sciences, Senior Scientists, Director of Regional Scientific and Educational Center “Holodomor, Holocaust, International Dialogue" L'viv Polytechnic National University, L'viv, Ukraine. Email: levukbs@ukr.net ORCID: 0000-0001-5100-0834

2 Doctor of Philosophy, Professor, Dean of the Faculty of History and Philosophy Borys Grinchenko Kyiv University, Kyiv, Ukraine. Email: olena.aleksandrova@yahoo.com ORCID: 0000-0003-0030-1367

${ }^{3}$ Doctor of Philosophy, Associate Professor at the Philosophy Department, Borys Grinchenko Kyiv University, Kyiv, Ukraine. Email: s.khrypko@kubg.edu.ua ORCID: 0000-0001-9426-4549

${ }^{4}$ Doctor of Philosophy, Associate Professor at the Philosophy and Cultural Studies Department, Admiral Makarov National Shipbuilding University, Mykolaiv, Ukraine. Email: iats2601@gmail.com ORCID: 0000-0002-8675-5118
} 


\section{Introduction}

Reflecting on the particular historical circumstances, the phenomenon of Ukrainian ethnical mentality has highlighted its crucial meaning through determining the borderlines of peaks and falls in national fate as well as in a personal life of each representative. It occurs in the process of the spiritual evolution of humanity, where any nation can disappear under the pressure of geopolitical realities or occupy an appropriate place in the historical process of the following epochs. Figurative thinking and rich imagination were always inherent in the Ukrainian world view that was a reason for presenting Ukraine as the mystical Phoenix which is followed in scientific literature and fiction. A fatal coincidence of figurative and literal permitted to argue (despite all stylistic canons) "that there was a manifestation of God's miracle through which Ukraine existed physically as well as spiritually despite all tragedies of its fate" (Lozko, 1995, p. 49).

Historically, Ukraine endured the extended turmoil connected with political, religious, ideological, territorial, and even ecological factors that collapsed the stability of being, completely ruined national security, contradicted with national values and bases of ethnical mentality; consequently, they impeded the natural way of Ukrainian spiritual evolution. Geopolitics is inextricably connected with the historical fate of the nation, penetrates its geographical and political parallels. According to historical situations, internal or external circumstances, some combination of geopolitical factors determines the crucial chance of so-called "new turn of history" or leads to the poly-contextual crisis, cultural decay, moral and spiritual degradation that is "fatal spin of spiral for Ukraine" characterized as a "phenomenon of decay".

The decay could be followed in the dimension of Ukrainian anthroponomics, for instance, the authentic names were forgiven, and the new foreign names were adopted. Furthermore, the ancient history was abandoned with a gradual name forgiving. We can support the thought that a nation is alive, while name lives. The personal names were the witnesses of the history as well as its symbols (as the names facilitate to provide general historical study). A name is always associated with somebody or something, as it is the essence of a thing and a distinguished person's feature. In the other words, nothing exists still it is necessary to name it, and vice versa, the necessity to vanish something is symbolically described by the formula: "Don't even mention its name" (Khrypko \& latsenko, 2019 a).

Moreover, the marginal and assimilative tendencies concern a sphere of Ukrainian surnames. The change of surnames is much more dramatic, as the whole history of family, region, and country demonstrates. "A name is a choice, motivation, aspirations, a parents' gift. A surname is inheritance. It is a clan's sign, family's code, a symbol that connects us with a world of our predecessors, with a history of our family. A name is something that is acquired "here and now"; however, a surname is a voice from eternity, a gift from the predecessors' will" (Khrypko \& latsenko, 2019 b). Fashion or personal thoughts regarding the loss of Ukrainian authentic name-surname giving tendencies led to the cultural marginalization and ethnic traditions' violation.

The features of decay are the issue of scientific study; however, the reasons are widely discussed. The decay incorporates geopolitical realities, risks connected with the national ideas as well as ethnic and religious factors. Regarding the last two factors, "one of the eternal tragedy of the Ukrainians that has lasted since the birth of the nation, is the lack of religious unity between the regions, people and their spiritual tutors, dominance of different religious denominations..." (Religious..., 1994, p.36). 
The practice proves the undeniable dominance of politics over religion. Nevertheless, a religious source is considered to be the main category of power in the whole history of ethnos despite the authority's representation. The political history revealed that an institution "corresponded to all political plans and the secular authority" (Religious..., 1994, p.36) was required by the representatives of the Ukrainian political elite instead of a religious institution reflected all spiritual and national values of the Ukrainian nation.

The factor of decay has its beginning in "the dissonance" of national aspiration and political choice. Gradually, it integrated into the spiritual experience of the nation, its historical memory, and the world view which was reflected in Ukrainian ethnical mentality and religious manifestation that were the direct reference to national idea's realization in general and national security in particular.

Culture of national being is the basic priority in the establishment and representation of national security. A priori, national security was used as the ground for state existence since the time of ancient Egypt and Rome (Nikitin, 2015). For instance, according to Cicero the issue of national security occupied an appropriate place as "first of all, every kind of animal obtained a gift to defend themselves... escape everything harmful and gain all necessary things to sustain their living" (Cicero, 1999, p. 31). Early in the $19^{\text {th }}$ century, a conception of national security developed as a main principle of defense against Napoleon's wars of conquest, it ideologically supported the "Holy Alliance" of European countries to secure statehood, personal and social security on the legal basis (Rothschild, 1995). Therefore, the correlation between geopolitical, state, national, social, mentality, and personal factors has been urgent for the communities and nations during the whole history of human civilization.

The initial aim of the paper is to follow geopolitical and geo-psychological features of national, mentality, religious culture, and ideas of national security through structural analysis and hermeneutic methodology; to represent the unique "borderline" of Ukrainian geopolitical, cultural, and mental being; to highlight the character and sources of marginal tendencies in Ukrainian spiritual culture. The additional goal is to demonstrate that the legal establishment of national security principles should be based on the cultural and mental factors.

\section{Discussion}

Turning the historical pages, we could notice that the first epochal and contradicted action connected with geopolitical needs and spiritual realities were the governmental decisions of the duke Volodymyr, who "established Christianity by fire and sword" (Lozko, 1995, p.203). Due to the critical comments of the researchers, there was an artificial process of duke's actions; the fact of Christianization and the process of belief change were alien; there was a context of intentional "humiliation" of authentic religious beliefs; the results of the forced Ukraine Christianization were far from brilliant (Lozko, 1995, p.201). Hence, there was a "power demonstration" from the duke; the world view leap into "another being". The complicated, contradicted process of the Eastern pagan religious beliefs' substitution lasted for a long period of time. Moreover, a crisis of ancient Ukrainian values and sanctuaries led to the discrepancy between the general and personal perception of the world, where Christianity became as some canon of interpersonal relations only when the time had passed (Religious..., 1994, pp.23-33).

Unfortunately, the factors were a factual reason for a substitution of Christian doctrine values for the political priorities of Christianization in the light of political process that provided an opportunity to consider the fact of Christianity's acceptance as "a spiritual revolution from above" (Such scientists as G. Lozko, P. Kononenko, S. Plachynda, V. Schayan, L. Sylenko support the idea). Some value judgments can be noticed in the literature regarding the religious studies, for instance, "... an 
action that has a deep impact on the whole history of the Eastern Slavs". Nevertheless, the action caused "the contradiction" between geopolitical calculations and spiritual value of Volodymyr's actions (Religious..., 1994, p.21). The ancient dimension of spiritual beliefs was not changed, instead, it was ruined: everything old was vanished for the new one. Having destroyed the balance of the whole world view (ethnical mentality), the forced Christianization created "a range of mental deformations" in the national consciousness: unconditional acceptance of alien "schemes and considerations about the national past", indifference to the national values, hostility to the national theme (collaborative psychology) or hypertrophic mythologizing, marginal tendencies appearance, etc. All abovementioned is considered (in periodicals and scientific literature) as a defensive reaction to oppression and denial of national dignity (Lozko, 1995).

A role of the religious factor in the history of national spirituality as well as in the governmental processes is simultaneously complicated and contradicted. The dominant context of Volodymyr's political step (according to which Ukraine was excluded from the third world countries and forced to be counted by the global community of that time) should have been state making and have become a spiritual element united the whole political history of the Ukrainian nation. However, the reality was just the opposite - statehood and spiritual decay in the society. The actions of 988 destroyed the ideas of "national homogeneity" (History, 1993, p. 501): the magi (wise men) - natural aristocracy was left in the past; "national creative character", the base of Ukrainian mentality was completely destroyed. The head of Ukrainian organization of the religious studies A. Kolodnyj mentioned that "Having accepted Christianity, Ukraine-Rus did not foresee that it would have found itself between two cultures - the Western and Eastern, and that the difference would have influenced on the political, economic, ethnic, spiritual and religious life" (Religious..., 1994, p.42). Having compared the situation with a festering wound, the researcher stressed that it "had divided the Ukrainians for centuries, consequently, they became easy prey of various states and churches" (Religious..., 1994, pp.42-43). The time only exacerbated the state of decay that was transformed into a fatal wound of spiritual alienation, and divided the Ukrainians due to ethos, denominations, citizenship, etc. Therefore, having been split by territory of living, political and religious views, social status, the Ukrainians had lost a sense of national spiritual unity. Having supported different political systems and empires, they destructed themselves. The multi-dimensional character of the factors of decay left a vivid trace on Ukrainian character, national mentality, and in turn impacted on the modern history of statehood. It refers to the absence of an idea regarding state traditions in Ukrainian mentality, as a result, numerous of the alternative extremes have appeared - from the monarchical sources of the national world view that "cannot be partially rejected or accepted" as "it comes from our past" (History..., 1993, p.465) to the historical lack of statehood that is completely logical and theoretical nonsense. The example depicts one of the vivid manifestations - oblivion that is typical even for the political elite nowadays. Nevertheless, despite all the negative consequences, there is a positive side. Any destructive power caused some opposite power the confrontation of which became experience, imprinted in the memory, and formed an opportunistic tendency of national mentality due to which the Ukrainians did not disappear or dissolve in the other ethnic groups and cultures.

The main and central factor of the situation is a geopolitical factor of crossroads or borderline that has accompanied Ukraine since nowadays. The "borderline" issue is the main for Ukraine in the light of its whole history. The reason of a distinctive border between the East and West is not significantly a geographical factor, the importance of which connected with the existence of twoterritorial Ukraine (however, an idea of unity has been historically questionable). Ukraine is a territory of two world mono religions - Christianity and Islam; consequently, there are two types of religious mentality (that oppose each other far apart from the theological bases). The issue of the religious 
diversity is brighter as Ukraine is at the intersection of the central denominations of Christianity - the Orthodox and Catholic Church. The factor of two denominations presence obtained co-existence in the form of Union. It should be mentioned that the Uniate Church became a factor of the national identification at the regional level. Besides the geographical factor, the borderline issue includes a political aspect. Historically, Ukraine was offered fundamentally different ways of historical development, namely, the Western way which included openness, democracy, reforms, scientific ground, and the Eastern way in the light of Russian understanding with the opposite features. Among them were conservatism, totalitarianism, ideologically closed nature, tsar and priests' worship. The factors were exacerbated by the atmosphere of colossus trend; moreover, the constant desire to be the Third Rome was inherent in Moscow state, Russian Empire and the Soviet Union. Ukrainian hesitations between the Western democracies with their religion on the one hand, and the constant Russian claims of being "The Third Rome" on the other hand, caused state, territorial, national, and religious insecurity. Ukrainian territory and nation was constantly an object of hostile invasion from the neighbors.

Ukrainian historical, geographical, and political location was reflected in mentality as a complex of inferiority. Some scientists, for instance A. Kultchytsky, determine one additional component of Ukrainian character - "masochism" which describes suffering as a normal state, from which even some pleasure can be gained. The same bases established another subconscious component of Ukrainian mentality - "a complex of disgruntled", the components of which were hesitations, uncertainty, dependence, patience, shyness, psychological state of learned helplessness. The enumerated features established the fertile ground for Gospel ideas spreading of waiting for a Savior. A wish to compensate or chase all worldly goods coherently was inherent in the Christian doctrine regarding accepting suffering and obtaining good in heaven. Geopolitical circumstances created such a psychological state in Ukrainian society according to which a man was "at full capacity" (Kolodny, 1996, p.7). A state of geopolitical subordination established "a desire to gain and compensate all the losses and pushed to the thoughts of God's intercession" (Kolodny, 1996, p.7). Moreover, due to the representatives of the Ukrainian religious studies, the Ukrainians who were in the state of constant survival, balancing between life and death (and often the scales were in favor of the last option), led to the belief of "the Kingdom of Truth, Brotherhood and Humanity" that was possible exceptionally within God's will and intercession (Religious..., 1994, p.52).

Ukrainian servitude exacerbated by the necessity to subordinate to the other ethnical groups as well as to be their representatives that caused gradual spiritual, mentality assimilation, changes in cultural values and ideas in favor of the other cultures. The loss of any national traits, suffering and deprived conditions of living formed so-called complex of provincial. All the above-mentioned features of Ukrainian historical being are the characteristics of the colonized ethnical group that imprinted in the religious sphere. The deficiency of canonically presented Ukrainian Orthodox Church caused misconnection of "We" in the context of a religious community with its national depiction. "I am a representative of Orthodox Church" does not mean that "I am Ukrainian", it exclusively highlights an abstract denomination. The situation became acute during the Russian Empire, when Ukrainian autocephaly was beyond the dreams, and the Ukrainians obtained a name "malorosy" (little brothers of Russians). The dynamic of national consciousness was violated - national feelings were substituted by the religious, religious "We" contradicted to national "We", and even became a reason of selfdestruction and national "dispersion". The last tendency is described in the history of Ukrainian emigration.

The nature of statehood could not tolerate a vacuum. Having assimilated into the different ethnical groups, political systems, the Ukrainians lost their national features and forgot their origins. 
Polish and Russian influence led to the situation when the Ukrainians were outcasts in "our - not their native country". The religious factor was powerless regarding statehood issues. The reason was in its artificial nature. The Christianity came "ready-made" into Ukrainian lands, it was not a product of national organic development, as a result, it did not become a holy thing that could be identified with a synonym of national life and be regarded as national peculiarity. Furthermore, the Orthodox Church was not at the level of sanctity which permitted to connect its infringement with state or property violation. The Orthodox issues could not create any holy war under the circumstances of internal assaults. It was not an idea or goal for which any life could be sacrificed. The modern scientist V. Moscalets' wrote: "Christianity was forcefully introduced in Kyiv Rus, and initially, people did not accept it. The crucial tragic factor of mass acceptance was the Mongol-Tatar invasion. Being incapable to resist the terrible calamities, people found spiritual support, consolation, and hope in the Christian doctrine. Regarding the purifying force of suffering, its benefit for the human soul, it was considered that it could save a soul for eternal bliss in heaven" (Moskalets, 1993, p.69). Consequently, during the Mongol-Tatar invasion, Christianity became "the unique method of spiritual support and psychotherapy that compensated the worldly sufferings by religious consolation" (Moskalets, 1993, p.72). Nevertheless, despite being "psychotherapy consolation", Christianity was not "a factor of spiritual union of Rus in the struggle with the infidels" (Religious..., 1994, p.25). Early Christianity could not become a "factor of dukes' argues elimination as well as facilitate education spreading among people", later, it was incapable to be "a holy thing, infringement of which, was equal to life violation and defense of which could be regarded as a holy duty" (Religious..., 1994, p.35). A. Kolodny wrote that "Christian religion did not spiritually unite Rus. The proof of that was a defeat in the war with Tatar-Mongols" (Religious..., 1994, pp.34-35). The further geopolitical cataclysms led to "the complete loss of independence and prevented our nation from normal development. On the other hand, they strengthened the psychological attraction of Christianity, on the other hand, a church became the only institution which stored and developed Ukrainian spirit, culture and had a decisive influence on national consciousness establishment" (Moskalets, 1993, p.71; Zmyr, 1991).

History proves a conclusion that any religion does not have an organic connection with ethnical cultural tradition, however, it builds artificial connections under geopolitical circumstances, and "it is incorporated into a context of spiritual life in a modified form and plays an integrational role in national history over a period of time" (Religious..., 1994, p.34). The classical illustration of the conclusion regarding a contradictive role of the religious factor during the periods of the Ukrainian state, spiritual and national Renaissance was an example of Pereyaslav Agreement (1654) that within the context of the whole time of Cossacks was regarded as the best page of spiritual national being. The Orthodox focus of Cossacks' relations with the Moscow nobility secured the success of the treaty on the one hand; nevertheless, on the other hand, a way for denationalization and state destruction was open. Local success under those geopolitical realities turned into centuries of decay and Ukraine's removal from the international arena. The next colonial fate of Ukraine as a state and nation was fatal as well as catastrophic due to its constant dependence on the imperial authorities that became total, artificial and alien.

Still, so-called "bases" stayed solid. "The immutability" secures Ukrainian ethnical mentality, especially its geopolitical feature which reflects a specific "handwriting", "style" of the world's acceptance, absorbs a long process of national spiritual being under the constant social and cultural circumstances. The rich ancient moral peasant "culture of sowers" (History..., 1993, p.449), the spirit of grain-growers, the cult of Ukrainian family are "the bases" that have stored an idea of Ukrainian statehood through all turmoil and geopolitical oblivion as well as have caused original religious features of Ukrainian spirituality existed since nowadays. 
Consequently, geo-psychological factors play a crucial role in the process of religious world view establishment in addition to the geopolitical factor. A man as a human being can exceptionally consider the Universe by his mind. However, geo-psychology of a particular ethnical group can embrace landscape views, some distinctive peculiarities of nature that are the components of the geographical dimension of the general definition of Motherland. Character of mind, perception, emotional sphere, and other details of individual and ethnical psychology are formed under the impact of visible geography of living. Having imprinted in the mentality of ethnical group, they play a crucial role as geopsychological reactions in religious manifestations. The ancient philosophers stressed the importance of a climatic feature in the process of psychological establishment: "The Earth and its character lead different nations by various roads to God's understanding" (Grygoriiv, 1949, p.5). The impact of "geographical location... and natural peculiarities... on the religious and moral creations" was highlighted by M. Kostomarov in "Two Russian Nations". If a nation changes the geography of its localization, then it will be completely transformed in religion, culture, moral, art and science dimensions, etc. according to the new area during the recent generations. Having mentioned the fact of Ukrainian love for poetry, M. Kostomarov wrote: "The Ukrainians are deeply religious... It influences on the poetical mood that is determined by spiritual structure" (Kostomarov, 1991, p.49).

"The mandatory impact of landscape on almost all organisms was observed by Yu. Barabash, L. Berg, L. Gumiliov, P. Savytsky. The methodology of research was enriched by the following definitions as "place of birth", "place of development", "a-mentality", "mental memory", "landscape archetypes of national consciousness" (Barabash, 1994). The Ukrainian geopolitical state of territory separation, its "vulnerability" and extant of its lands caused the tragedy of national history. Furthermore, the presence of the religious factor in society created a situation of "being between two worlds" according to V. Yaniv. Due to V. Moskalets, the insecure state establishes situations when a life is under constant threat (as well as a threat of property loss exists). Therefore, people seek hope and consolation in God (Moskalets, 1993, p.70). The effect from the factor in geopolitical, geo-psychological, and religious spheres of Ukrainian being is described by the scientist from Ukrainian diaspora V. Yaniv. "When the difference between the simple and true being is clearly distinctive, then a man endeavors to find the closest relation to transcendence in his being... A life is transformed into the highest form... Typically, Christian belief was transcendence for the nations with Christian culture and hope became an ideal that crossed the borders of life" (Yaniv, 1966, p. 181). It should be mentioned that the context of gentle character and spirit of tolerance as the central factors of the national character is followed in all geopsychological manifestations of the Eastern Slavs. For instance, D. Mordovtsev in the paper "A Tribe of Maloros" included in the issue of "Picturesque Russia" (1897) wrote: "There is some subtle... internal aristocratic nature of Ukrainian spirit and delicacy (refinement)... of the spirit created national love for the picturesque landscape. Their villages are covered by gardens. A Ukrainian man is religious with some lyricism... Moreover, a soft, deeply compassionate heart is hidden under his serious and austere look". Nevertheless, the essential difference between the Western and Eastern Ukrainian regions caused mental sets contradicting that could not be eliminated by mutual enrichment or mutual removal. The mountainous nature of Galicia exacerbated separatist tendencies of the Ukrainian population; they tried to shield themselves from the Polish, Russians, and even the Ukrainians from Naddniprianschina or Volyn (Grygoriiv, 1949, p. 301). The common history highlights that the representatives of Ukrainian Western and Eastern regions doubted about the Ukrainian nature of their neighbors. The result was a division between the "Western" and "Eastern" Ukrainians involved in the wars on their native land that defended the interests of alien empires and political systems. The Ukrainians killed each other on their land for the sake of different ideological values. The consequences of the Ukrainian regions' difference caused decay in the system of geo-psychological reactions as well 
as in the spiritual sphere of national being. Thus, a connection between the national religious features and the ethnical landscape deserves scientific attention.

The proof and identical recognition via dialogue is one of the productive strategies of tolerant communication. A dialogue became an urgent theme of social and philosophic reflection at the beginning of the $20^{\text {th }}$ century. Nowadays, the subject of dialogue reveals new unexpected dimensions of modern communication under the circumstances of ethnical and cultural contradictions, military conflicts. The separatists' tendencies violated the stability of national and cultural space of Ukraine, the post-modern fashion on the new names (or nick, code names) affected the cultural stability of national anthroponomics (Khrypko, latsenko, 2019 a).

A comparison can be made according to the factor of landscape. A change of national consciousness into religious one occurred in open prairie Western Ukraine, open to all winds (literary and figuratively): the particular "I am Ukrainian" transformed into "We are the Orthodox believers". The Union was typically to the Western Ukrainian lands, the reason was in popularity of Greek Catholics. The Ukrainian Greek Catholic Church was widely accepted as a church of the Western Ukraine.

\section{Conclusions}

Having analyzed the synthesis of geopolitical and geo-psychological factors in the process of Ukrainian religious establishment, we can make the following conclusions:

- Geo-policy and geo-psychology are the initial and main determinants that influenced on Ukrainian national mentality establishment. They caused the unique nature of the mental phenomenon that characterized as a synthesis of known and unknown, effective and emotional, past and future, which could be followed in the national being despite any desire of their manifestations.

- The distinctive difference in the landscape of Eastern and Western Ukraine determined the dramatic polarity of the regional mental orientations that played a fatal role in Ukrainian social history.

- Geo-political circumstances (enhanced by the constant presence of "borderline") were not in favor of unity in Ukrainian history. Moreover, it caused "instability" and "split" of Ukrainian being as well as national mentality displays. The marginal tendencies of Ukrainian mentality are derived from geopolitical factors in the history of national being.

- The special character of geopolitical and landscape factors established Ukrainian religious inclination that permitted to determine "deep religious nature" as the main feature of national mentality. Religion is the deep and hidden dimension of spiritual life where the unique combination of features is gradually formed. The process highlights the originality of national mentality and character determined by the peculiarities of national historical development. Nevertheless, the role of religion in the history of the Ukrainian nation is controversial and complicated. Religion was an instrument of disintegration and oppression as well as an instrument of struggle against national enslavement, a factor of ethnic integration and national consciousness.

- The real state of national security is determined by the existed or potential threats mandatory connected with modern evaluation and prediction according to their internal or external order. Still, it is impossible to create the rational contractions to all possible threats; they cannot be mentioned in legal acts. Any legislator does not know future; however, the national memory is able to predict it. The legal system can be based only on the established patterns, on causes and effects. Consequently, legislation is able to construct just general principles - stability, identification, and elimination of 
threats. Mental, cultural, and historical memory can imprint everything that is beyond the capacity of legal documents and become a basis of national security and dignity realization.

\section{References}

Badzio, Yu. (2000). National Idea and National Issue. Kyiv: Flame.

Barabash, Yu. (1994). "Place Development" or Do You Know a Ukrainian Night? (National Landscape as a Mental Factor by N.V. Gogol). Journal of Philosophy and Sociology Thought, 7-8, 135-136.

Cicero, M. T. (1999). On the Republic; On the Laws; On Old Age; On Friendship; On Responsibilities; Speeches; Letters. Translated and commented by E. Liapustin. Moscow: Thought.

Grygoriiv, N. (1941). Ukrainian National Character. Winnipeg: Manitoba.

History of Ukrainian Philosophy (1993). Kyiv: Lybid.

Khrypko S., \& latsenko G. (2019 a). Philosophy of a Name: Ukrainian Context. Beytulhikme: An International Journal of Philosophy, 9(2), 437-451. Retrieved from:

http://www.beytulhikme.org/OncekiSayilarDetay.aspx?Sayi=9:2

Khrypko S., \& latsenko G. (2019 b). Philosophy of a Surname: Ukrainian Context. Beytulhikme: An International Journal of Philosophy, 9(4), 899-912. Retrieved from:

http://www.beytulhikme.org/OncekiSayilarDetay.aspx?Sayi=9:4

Kolodny, A., \& Phylypovych L. (1996). Ukrainian Religious Spirituality: Manifestations, Figures, State. Lviv: Logos.

Kononenko, P. (1996). Ukrainian Studies. Kyiv: Lybid.

Kostomarov, N. (1991). Two Russian Nations. Kyiv: Maydan.

Lozko, G. (1995). Ukrainian National Studies. Kyiv: Zodiak-EKO.

Moskalets, V. (1993). Religious as a Feature of Ukrainian National Character. Journal of Philosophy and Sociology Thought, 1, 67-79.

Nikitin, Yu. (2015). National Security of Ukraine under the Modern Circumstances: Risks and Factors of Impact. Juridical Science, 2, 141-147.

Religious in Spiritual Life of the Ukrainians. (1994). Kyiv: Scientific Thought.

Rothschild, E. (1995). What is Security? Journal Dacdalus, 61-65.

Yaniv, V. (1966). Ukrainian Religious Nature from Ethnical and Psychological View. Religion in a Life of Ukrainian Nation. A Collection of Conference Materials. Munich-Paris.

Zmyr, V. (1991). On the Way to Yourself (History of Ukrainian Consciousness). Journal of Philosophy and Sociology Thought, 1, 144-162. 